\title{
Quimiofilatelia
}

O primeiro selo postal adesivo a ser usado num serviço postal público data de 1 de maio de 1840. 0 famoso Penny Black, começou a circular no Reino Unido e tinha como imagem o perfil da Rainha Vitória. A partir desta altura os selos começaram a atrair a atenção de colecionadores (e não só) pela singularidade do seu simbolismo e grafismo diverso. Ao longo dos séculos, múltiplos eventos, personalidades e temáticas ficaram imortalizados em selos em todo o planeta! A química em particular não é exceção. São diversos os selos que abordam a temática da química, também em Portugal. Espero que tenham ficado curiosos para descobrir os selos da química!

Veja mais em publications.iupac.org/ci/indexes/ stamps.html.

$>$

Vasco Bonifácio

vasco.bonifacio@tecnico.ulisboa.pt
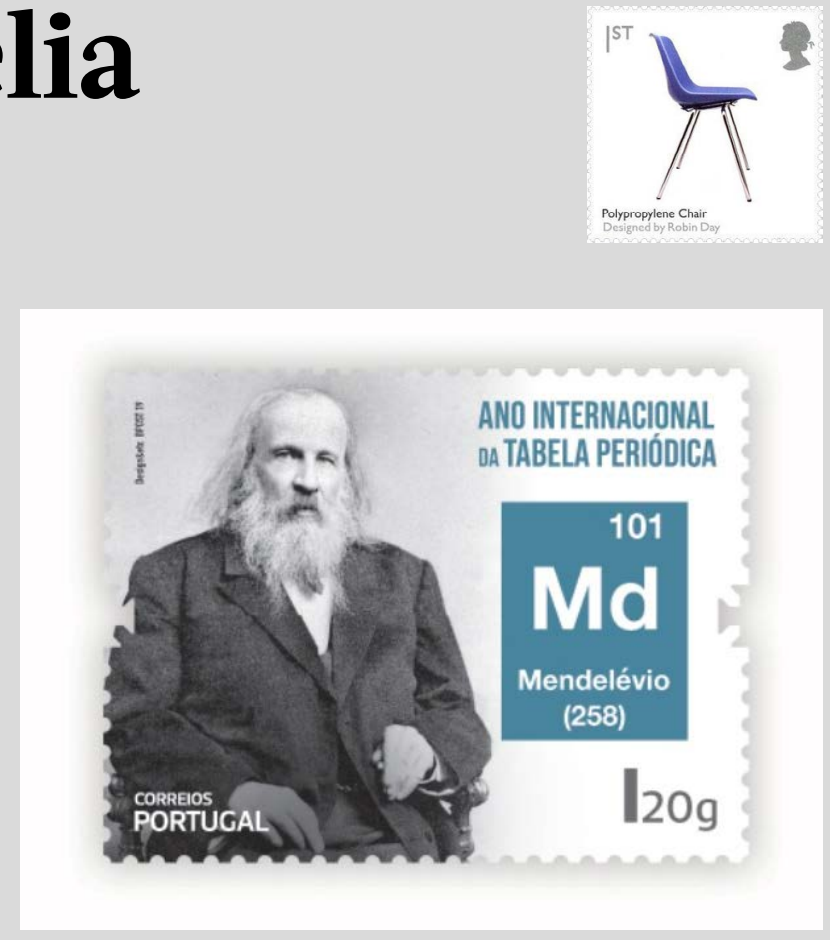

Emissão filatélica sobre o Ano Internacional da Tabela Periódica em 2019. Crédito: CTT.

\section{REACTIOOSN Química em Blocos}

\section{Taurine $\mid \mathrm{C}_{2} \mathrm{H}_{7} \mathrm{NO}_{3} \mathrm{~S}$}

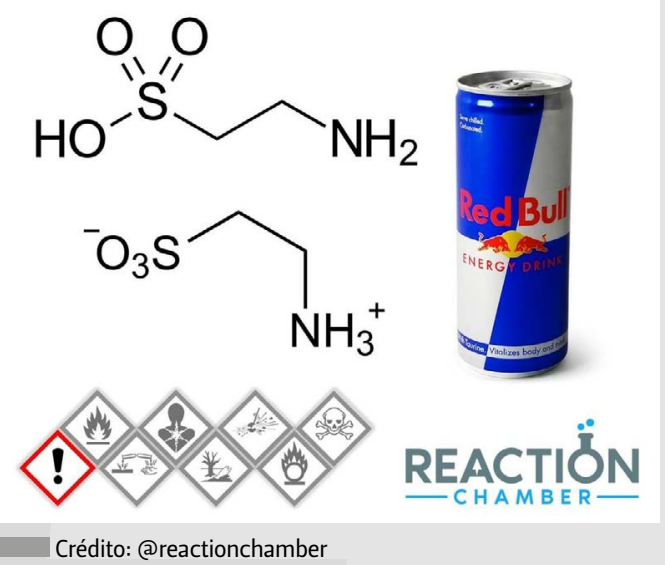

Reaction Chamber é uma conta do Instagram que mostra a química que nos rodeia. Um exemplo selecionado é a taurina, um dos ácidos aminossulfónicos mais abundantes no nosso cérebro, medula espinal, coração, músculos, retina e em quase todos os tecidos do nosso corpo! Esta pequena molécula pode ser encontrada de forma natural na carne, no peixe e derivados do leite, incluindo o humano. A taurina também está disponível como suplemento alimentar e popularizou-se através da bebida energética Red Bull. É caso para dizer: a química dá-te asas!

\section{Veja mais em instagram.com/reactionchamber.}

\section{Vasco Bonifácio}

vasco.bonifacio@tecnico.ulisboa.pt 